\title{
Productive Response of Pelibuey Sheep to Supplementation in the Stretching Season in the Dry Tropic
}

\author{
Aguirre Herminio Aniano, Gasga Pérez Lauro*, Peláez Estrada Urfila Victoria, \\ Galindo Arturo De la Rosa, Lozano Aguirre Eugenia, Mondragón Calderón Uriel
}

Tecnológico Nacional de México, Instituto Tecnológico de Pinotepa, Oaxaca, México

Email: ^lauro.gp@pinotepa.tecnm.mx

How to cite this paper: Aniano, A.H., Lauro. G.P., Victoria, P.E.U., De la Rosa, G.A., Eugenia, L.A. and Uriel, M.C. (2021) Productive Response of Pelibuey Sheep to Supplementation in the Stretching Season in the Dry Tropic. American Journal of Plant Sciences, 12, 1319-1327.

https://doi.org/10.4236/ajps.2021.129092

Received: July 20, 2021

Accepted: August 31, 2021

Published: September 3, 2021

Copyright $\odot 2021$ by author(s) and Scientific Research Publishing Inc. This work is licensed under the Creative Commons Attribution International License (CC BY 4.0).

http://creativecommons.org/licenses/by/4.0/

(c) (i) Open Access

\begin{abstract}
Sheep meat production in the dry tropics of Mexico is low in the dry season, due to lack of forage, therefore, strategic supplementation is important to avoid weight loss in animals; The research was carried out from August 15 to December 15, 2020 in order to evaluate the productive response of pelibuey sheep in confinement, fed with pangola grass hay $(\mathrm{GH})$, plains grass silage (PGS) and supplemented with commercial feed (CF) in the dry season. 16 sheep of the same weight and age were used, four treatments were evaluated in them, in a completely random design; the treatments were four levels of supplement $0,0.1,0.2$ and $0.3 \mathrm{~kg}$ of AC fed with HP and PGS. Sheep were dewormed at the beginning of the experiment and housed in individual cages. The variables were: dry matter intake, daily weight gain (DWG) and DM digestibility. DM consumption was different $(\mathrm{P}<0.01)$, the lowest consumption was $0.364 \mathrm{~kg}$ in treatment 1 (T1), with a maximum of $0.684 \mathrm{~kg}$ in T4; WDG was different $(\mathrm{P}<0.01)$, with a lower value of $0.044 \mathrm{~kg}^{-\mathrm{day}^{-1}}$ in $\mathrm{T} 1$ and a higher value of $0.112 \mathrm{~kg}$ in T4. The apparent digestibility of the dry matter showed a difference $(\mathrm{P}<0.01)$ which varied from 45.52 to $59.15 \%$ for $\mathrm{T} 1$ and $\mathrm{T} 4$, respectively. DM intake, WL gain, and DM digestibility increased with increasing supplement level at the levels studied.
\end{abstract}

\section{Keywords}

Intake, Weight Gain, Sheep, Digestibility

\section{Introduction}

In Mexico, the tropical region comprises approximately 56 million ha, representing $28 \%$ of the national territory; Most of this surface, which comprises $16 \%$, is lo- 
cated in the tropics with a warm subhumid climate and $12 \%$ corresponds to a warm humid climate [1]. The sheep inventory in the state of Oaxaca was 515, 782 heads and in the rural development district coast of 3, 249; with a slaughter percentage of 16.9 in relation to the total number of sheep in the state and $17.3 \%$ in the coastal development district, with a carcass meat yield of 17.8 and $17.7 \mathrm{~kg}$ at the state level and the Oaxacan coast, respectively [2].

In regions with a warm climate the cattle feed on native forage, stubbles, grain and sometimes supplemente with legume pods in the tropics [3] [4], animal production is low, a situation caused by the seasonality of rainfall which, in periods of low water where the availability of native forages decreases drastically, in turn, generates variations in the growth, production and quality of the forage, used for feeding livestock, which causes that the animals do not consume the quantity or quality of food required for maintenance and production, having losses in weight gain and milk production [5] [6]. In most ruminant producing tropical areas, they suffer nutritional stress either temporarily or permanently the most common deficiency in forages is energy; However, it has been mentioned that one of the main problems, limiting the productivity of cattle, under grazing conditions, is the protein deficiency in the forage, particularly in the dry season, since $22 \%$ to $49 \%$ of the Tropical forages are deficient in this nutrient [7] [8].

A viable alternative to improve animal production is strategic supplementation, the objective of which is to provide the animals with nutrients that forage does not provide in sufficient quantities [9], which can increase weight gain, decrease mortality, accelerate puberty and improve the percentage of calving, among other benefits; It has been shown that supplementation to ruminants both in grazing and in stables in the dry season, improves the productive parameters of animal production systems [10], profitability and quality of life of producers [11]. Therefore, this research was carried out with the objective of evaluating the productive behavior of pelibuey sheep under confinement conditions, fed with pangola grass hay, llanero grass silage and supplemented with commercial feed in the dry season, in San José Estancia Grande, Oaxaca, México.

\section{Materials and Methods}

The research was carried out at the Technological Institute of Pinotepa, in the academic unit in San José Estancia Grande, Oaxaca, Mexico, located at $16^{\circ} 22^{\prime}$ north latitude and $98^{\circ} 13^{\prime}$ west longitude, at 70 meters above sea level [2], with a warm subhumid climate, with rains of $800 \mathrm{~mm}$ in summer and an average annual temperature of $26.9^{\circ} \mathrm{C}$ [12]. Pangola grass hay, llanero silage and four supplement levels $0,0.1,0.2$ and $0.3 \mathrm{~kg} \cdot$ animal $^{-1} \cdot$ day $^{-1}$ was used as the base feed for all treatments; treatments were $\mathrm{T} 1$ : pangola grass hay + llanero silage without suplementation; T2: pangola grass hay + llanero silage $+0.1 \mathrm{~kg}$ commercial feed; T3: pangola grass hay + llanero silage $+0.2 \mathrm{~kg}$ commercial feed and T4: pangola grass hay + llanero silage $+0.3 \mathrm{~kg}$ commercial feed.

The sheep were dewormed the next day they arrived at the experiment site in- 
ternally with Albendaphorte to the $2.5 \%$ Co from the Animal Health and Welfare laboratory, taken twice every 20 days, the dose used was $1.5 \mathrm{ml}$ per $10 \mathrm{~kg}$ of live weight, and externally bathed with $12.5 \%$ Bovitraz of Amitraz from Bayer laboratory, the doses used was $2.0 \mathrm{ml}$ by litter water twice every 10 days and housed in individual cages, in which they randomly received the evaluated treatments. The feeding management consisted in offering daily a known quantity of plains silage (Andropogon gayanus) with $6 \%$ crude protein and $47.2 \%$ of dry matter digestibility and, at noon, it was offered the commercial Purina supplement with $12 \%$ crude protein and, finally ad libitum, pangola hay (Digitaria decumbens Stemp) $5.2 \%$ crude protein and $45.5 \%$ of dry matter digestibility was assigned; silage and hay rejects were weighed daily; the sheeps were weighed every eight days throughout the experimental period. The supplement was weighed daily on an Ohaus brand granataria scale and was offered individually to each sheep in plastic buckets during the hottest hours of 2:00 p.m.

The variables measured were daily dry matter intake, which was determined by adding the dry matter consumed from silage, pangola hay and the supplement, the daily weight gain was obtained by dividing the accumulated weight gain throughout the experimental period between the time that it is hard and, the apparent digestibility of the dry matter was determined using the technique of total collection of faeces.

To study the effect of the treatments on the live weight gain of the sheep, the consumption of dry matter and the apparent digestibility of the dry matter, were analyzed statisticament by analysis of variance for a completely random design, using the PROC GLM procedure the SAS [13] program and the treatments means were compared using the Tukey test ( $\alpha=0.05$ ). To analyze the type of response exhibited by weight gain, due to the effect of supplementation levels imposed by the studied treatments, the orthogonal polynomial technique and regression techniques were used. The analysis in Table 1 is given by the company PURINA (2019).

\section{Results and Discussions}

\section{Dry matter consumption (DMC)}

The average DMC in response to the effect of the studied treatments are con-

Table 1. Nutritional composition of commercial food used as supplement.

\begin{tabular}{cc}
\hline Nutrient & Unit of measure (\%) \\
\hline Humidity & 12.00 Maximum \\
Proteín & 12.00 Minimum \\
Fat & 2.00 Minimum \\
Fiber & 26.00 Maximum \\
Ashes & 20.00 Maximum \\
Nitrogen-free Extrac & 23.00 Per diference \\
Calcium & 4.60 Maximum \\
Fosphorus & 0.40 Minimum
\end{tabular}


centrated in Table 2, whose analysis shows highly significant differences $(\mathrm{P}<$ 0.01 ) between treatments, with a lower daily consumption of $0.364 \mathrm{~kg}$ per sheep in treatment 1 and a higher consumption of $0.684 \mathrm{~kg}$ occurred in T4.

Treatment 1 was different $(\mathrm{P}<0.05)$ to the dry matter $(\mathrm{DM})$ consumption observed in treatments 2, 3 and 4 and, represented $77.4 \%, 62.7 \%$ and $53.4 \%$ of the consumption achieved in these last treatments, respectively; Similarly, the treatments in which the sheep were supplemented T2, T3 and T4 were different from each other $(\mathrm{P}<0.01)$, the consumption achieved in $\mathrm{T} 4$ being higher $(\mathrm{P}<0.05)$ in $45.5 \%$ and $17.9 \%$ than the intakes observed in treatments 2 and 3, respectively, in general the treatments in which the sheep were supplemented on average were higher $(\mathrm{P}<0.05)$ in $58.7 \%$ than the consumption obtained in $\mathrm{T} 1$.

In general terms, by increasing the level of supplement to sheep, the consumption of dry matter increased significantly, however these consumptions are lower than those reported by [14] who on average observed consumption of $1.11 \mathrm{~kg}$ DM per sheep.day ${ }^{-1}$, when substitute sugarcane molasses for Algarrobo Ceratonia siliqua pods in sheep rations at three levels, these differences may be due to the fact that the sheep used were heavier and the rations were made up of better quality ingredients; in the same way, they are different from those reported by [15] who report values ranging from 1.19 to $1.3 \mathrm{~kg} \mathrm{DM} \cdot$ sheep $^{-1} \cdot$ day $^{-1}$, in the same climate and place. However, they are similarly to the values reported by [16] whose DM intakes ranged from 0.55 to $0.76 \mathrm{~kg} \cdot \mathrm{animal}^{-1} \cdot \mathrm{day}^{-1}$.

The low dry matter intakes observed in this research may be due in part, to the fact that both the pangola grass hay and the plains grass silage had already matured, that is, when the content of cell walls presents a high value, low concentration protein and energy and low dry matter digestibility value. The observed behavior of the consumption of dry matter may be due to the fact that by adding a greater quantity of commercial food as a supplement, this improves the digestibility of the dry matter consumed, thereby increasing the rate of passage of what is ingested and, as a consequence, it allows the animal to have a higher

Table 2. Daily dry matter consumption of pelibuey sheep supplemented with commercial feed in the dry season, in San José Estancia Grande, Oaxaca, Mexico.

\begin{tabular}{ccc}
\hline Treatments & Consumtion $\left(\mathrm{Kg} \mathrm{DM}^{\left.- \text {animal }^{-1}\right)}\right.$ & EEM $^{*}$ \\
\hline T1 & $0.364^{\mathrm{a}^{* *}}$ & 0.023 \\
T2 & $0.470^{\mathrm{b}}$ & 0.025 \\
T3 & $0.580^{\mathrm{c}}$ & 0.025 \\
T4 & $0.684^{\mathrm{d}}$ & 0.027 \\
Average & $\mathbf{0 . 5 2 4}$ & \\
\hline
\end{tabular}

${ }^{\star}$ Standard error of the mean; ${ }^{*}$ Means with different literals in the column are different Tukey $(\mathrm{P}<0.05)$; $\mathrm{T} 1$ : Control treatment of pangola grass hay and plains grass silage; $\mathrm{T} 2$ : $0.1 \mathrm{~kg}$ of supplement per sheep per day, pangola hay and flat grass silage; T3: $0.2 \mathrm{~kg}$ of supplement per sheep per day, pangola grass hay and llanero silage and T4: $0.3 \mathrm{~kg}$ of commercial supplement per sheep per day, pangola grass hay and llanero silage. 


\section{DM consumption.}

\section{Daily weight gain}

The analysis of variance carried out for this variable showed a highly significant difference $(\mathrm{P}<0.01)$, where the highest weight gains $0.112 \mathrm{~kg}$ were observed in T4, and the lowest gain $0.044 \mathrm{~kg} \cdot \mathrm{animal}^{-1} \mathrm{day}^{-1}$ in $\mathrm{T} 1$. The average daily weight gains are concentrated in Table 3 , in which it is observed that treatment 1 was different $(\mathrm{P}<0.01)$ from treatments 2,3 and 4 , in the same way, treatment 2 showed differences $(\mathrm{P}<0.01)$ to treatments 3 and 4 , similarly, T3 and T4 presented differences $(\mathrm{P}<0.01)$ in this variable, due to the effect of treatments.

The weight gain achieved in T1 represented $69.8,52.4$ and $39.3 \%$ of the gain obtained in treatments 2, 3 and 4, respectively. Treatment 2 was superior $(\mathrm{P}<$ $0.01) 43.2 \%$ to treatment 1 , treatments 3 and 4 exceeded $(P<0.01) 90.9$ and $154.5 \%$ respectively to $\mathrm{T} 1$ and, on average, the treatments in which a supplement was used were superior in $96.2 \%$ to treatment 1 . On the other hand, T3 was $33.3 \%$ higher $(\mathrm{P}<0.01)$ than $\mathrm{T} 2$, and $\mathrm{T} 4$ surpassed $\mathrm{T} 3$ by $33.3 \%$. In general terms, it is observed that as the supplement to sheep was increased, the daily weight gain increased, this increase was sustained to the extent that a higher level of supplementary food was offered to the animals.

Although the daily weight gain in sheep increased, these were low, this possibly could be due to the fact that both the pangola grass hay and the llanero grass silage, did not have the adequate quality to contribute in quantity the nutrients (protein and energy) that the sheep required to produce a better weight gain, this can be strongly related to the low values of apparent digestibility of the dry matter of the evaluated treatments.

These values of daily weight gain are lower than those found by [14] who on average reports gain of $0.138 \mathrm{~kg} \cdot \mathrm{sheep}^{-1}$, said difference may be due to a higher quality of the rations evaluated; In the same way, the weight gain in this research was lower than that reported by [15], whose value ranged from 0.185 to 0.19 $\mathrm{kg} \cdot$ animal $^{-1} \cdot$ day $^{-1}$, when replacing cane molasses with Algarrobo pods (Ceratonia

Table 3. Daily weight gain of pelibuey sheep fed with pangola grass hay, llanero grass silage and commercial feed in the dry season, in San José Estancia Grande, Oaxaca, Mexico.

\begin{tabular}{ccc}
\hline Treatments & Weight gain $(\mathrm{Kg})$ & EEM $^{*}$ \\
\hline T1 & $0.044^{\mathrm{a} * *}$ & 0.002 \\
$\mathrm{~T} 2$ & $0.063^{\mathrm{b}}$ & 0.003 \\
$\mathrm{~T} 3$ & $0.084^{\mathrm{c}}$ & 0.003 \\
$\mathrm{~T} 4$ & $0.112^{\mathrm{d}}$ & 0.003 \\
Average & $\mathbf{0 . 0 7 6}$ &
\end{tabular}

${ }^{\star}$ Standard error of the mean; ${ }^{* *}$ Means with different literals in the column are different Tukey ( $\mathrm{P}<0.05$ ); T1: Control treatment of pangola grass hay and plains grass silage; $\mathrm{T} 2$ : $0.1 \mathrm{~kg}$ of supplement per sheep per day, pangola hay and flat grass silage; T3: $0.2 \mathrm{~kg}$ of supplement per sheep per day, pangola grass hay and llanero silage and T4: $0.3 \mathrm{~kg}$ of commercial supplement per sheep per day, pangola grass hay and llanero silage. 
siliqua); however, they are similar to those reported by [16] whose values ranged from 0.076 to $0.111 \mathrm{~kg}$ per.animal ${ }^{-1} \mathrm{day}^{1}$, when evaluating rations containing different proportions of parota pods (Enterolobium cyclocarpum) in young lambs.

The behavior exhibited of the daily weight gain, as a result of the treatments evaluated in this research, may be due to the fact that, by offering supplementary feed in increasing quantities to the sheep, the protein and energy intake was improved, thereby favored a better daily weight gain, in response to a higher consumption of feed per day, as can be seen in Table 1, and possibly to a better apparent digestibility of the dry matter consumed by the sheep, in the treatments studied.

\section{Productive response to supplementation}

In Figure 1 it is observed that the type of response exhibited by weight gain, due to the net supplementation effect, is linear, since when the sheep were offered $0.1 \mathrm{~kg}$ of DM of the commercial supplement, formulated for sheep, they gained $0.02 \mathrm{~kg} \mathrm{LW} \cdot \mathrm{day}^{-1}$, on the other hand, by increasing the amount of supplement to $0.2 \mathrm{~kg} \cdot$ animal $^{-1} \cdot \mathrm{day}^{-1}$, the sheep managed to gain $0.04 \mathrm{~kg} \cdot \mathrm{day}^{-1}$, in the same way by increasing the supplement level to $0.3 \mathrm{~kg} \cdot \mathrm{sheep}^{-1} \cdot$ day $^{-1}$ the sheep gained $0.068 \mathrm{~kg}$ of live weight. The equation that represents this phenomenon is WDG $=-0.01206+0.7247 \mathrm{X}$, with a coefficient of determination of $\mathrm{r}^{2}=0.955$, for the dry season.

In this graph, in general terms a linear response is observed, where by increasing the amount of supplement in the treatments, the response of the sheep was to increase the daily weight gain, however, these observed responses are low, which may be due to the fact that the diet offered to the sheep consisted of a large proportion of pangola grass hay, which presented a DM digestibility of $45.5 \%$, therefore, the contribution of nutrients such as protein and energy by the forage was low, which implies that the retention time of the intake in the rumen reticulum was longer, which negatively influenced the response of the sheep in weight gain.

This type of WG response to supplementation in the dry season coincides with that found by [14] [17], when evaluating supplementation levels in sheep in stables during the dry season and, with that reported by [2] for the dry season,

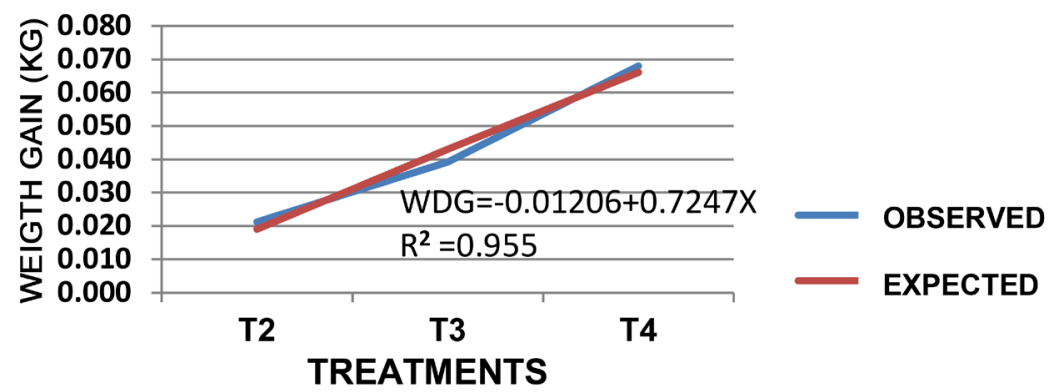

Figure 1. Productive response of pelibuey sheep, to protein energy supplementation, in confinement in the dry season, in San José Estancia Grande, Oaxaca, Mexico. 
under dry tropic conditions for grazing calves in a pangola meadow by substituting commercial feed for cacahuananche flour (Gliricidia sepium).

\section{Apparent dry matter digestibility (ADMD)}

The mean values of the ADMD are presented in Table 4, in which it can be seen that the lowest digestibility value $45.5 \%$ was presented in treatment 1 and the highest $59.15 \%$ in treatment 4 . A significant difference was found $(\mathrm{P}<0.05)$ between treatments 1 and 4 , with treatments 2,3 and 4 being equal $(P>0.05)$ in digestibility.

The behavior of this variable may be due to the fact that, by increasing the level of supplement in the treatment, this caused a positive effect on the ADMD consumed, since it improved substantially, which allowed increasing the consumption of daily DM Table 2 and, improved the daily weight gain Table 3. However, despite an improvement in the ADMD, it is unquestionable that these digestibility values do not allow high DM intakes and, consequently, there are low daily weight gain.

These results coincide with those recorded by [14], which fluctuate from $44 \%$ to $56.1 \%$ when evaluating with sheep, three levels of substitution of cane molasses for carob pods in the diets, in the same way with what was found by [18], who report DM digestibility values ADMD that varied from $47 \%$ to $57 \%$, by increasing the levels of supplementation to young bulls in stables, fed with pangola grass hay and llanero grass silage, the highest level of supplementation produced the best ADMD value.

\section{Conclusion}

According to the conditions in which the experiment was carried out and the results obtained, it can be concluded that supplementation with commercial feed at the levels used in this research, to pelibuey sheep fed with pangola grass hay and plains grass silage, improved the consumption of dry matter, the daily weight

Table 4. Apparent digestibility of daily dry matter consumed by pelibuey sheep fed with pangola grass hay, plains grass silage and commercial feed in the dry season, in San José Estancia Grande, Oaxaca, Mexico.

\begin{tabular}{ccc}
\hline Treatments & Digestibility (\%) & EEM $^{*}$ \\
\hline T1 & $45.52^{\mathrm{b} * *}$ & 1.22 \\
T2 & $48.00^{\mathrm{ab}}$ & 1.54 \\
T3 & $50.18^{\mathrm{ab}}$ & 1.25 \\
T4 & $59.15^{\mathrm{a}}$ & 1.95 \\
Average & 50.71 & \\
\hline
\end{tabular}

*Standard error of the mean; ${ }^{* *}$ Means with different literals in the column are different Tukey $(\mathrm{P}<0.05)$; T1: Control treatment of pangola grass hay and plains grass silage; $\mathrm{T} 2$ : $0.1 \mathrm{~kg}$ of supplement per sheep per day, pangola hay and flat grass silage; T3: $0.2 \mathrm{~kg}$ of supplement per sheep per day, pangola grass hay and llanero silage and T4: $0.3 \mathrm{~kg}$ of commercial supplement per sheep per day, pangola grass hay and llanero silage. 
gains and the digestibility of the dry matter of the evaluated treatments and, the productive response of the sheep increased, as the level of supplement in the treatments increased, the response being linear.

\section{Conflicts of Interest}

The authors declare no conflicts of interest regarding the publication of this paper.

\section{References}

[1] Claverán, A.R. (1991) Las praderas tropicales para la producción de leche. FIRABanco de México. Boletín Informativo, 228. Vol. XXIII, 47 p.

[2] INEGI (2010) Anuario Estadístico para el estado de Oaxaca. México, 465 p.

[3] Coppock, D.L. (1993) Grass Hay and Acacia Fruits: A Local Feeding System for Improved Calf Performance in Semi-Arid Ethiopia. Tropical Animal Health and Production, 25, 41-49. https://doi.org/10.1007/BF02236885

[4] Quiroz-Cardoso, F.S., Rojas-Hernández, J., Olivares-Pérez, E., Hernández-Castro, R., Hernández-Guillén, A., Córdova-Izquierdo, A., Villa-Mancera and Abdel-Fattah, S. (2015) Composición nutricional e índice de palatabilidad relativa de los frutos de tres acacias en la alimentación de ovejas y cabras. Archivos de Medicina Veterinaria, 47, 33-38. https://doi.org/10.4067/S0301-732X2015000100007

[5] Barahona, R., Sánchez, S.M., Murguitio, E. and Chará, J. (2014) Contribución de la Leucaena leucocephala Lam (de Wit) a la oferta y oferta y digestibilidad de nutrientes y las emisiones de metano entérico en bovinos pastoreando en sistemas silvopastoriles intensivos. Revista Carta Fedegán, 140, 66-69.

[6] Mayren-Mendoza, F.J., Rojas-García, A.R., Maldonado-Peralta, M.A., RamírezReynoso, O., Herrera-Pérez, J., Torres-Salado, N., Sánchez-Santillán, P., Bottini Luzardo, M.B. and Hernández-Garay, A. (2018) Comportamiento productivo de ovinos pelibuey en pastoreo suplementados con follaje de Guazuma ulmifolia Lam. Agroproductividad, 11, 29-33. https://www.researchgate.net/publication/326426796

[7] Paladines, O. and Leal, J.A. (1979) Manejo y productividad de las praderas en los Llanos Orientales de Colombia. In: Tergas, L. and Sánchez, P.A., Eds., Herbivore Nutrition in the Subtropics and Tropics, The Science Press, Craighall, 145-166.

[8] Huerta, B.M. (1993) Suplementación de rumiantes en pastoreo. In: Ortega, C.M.E. and Mendoza, G.D., Eds., Memoria del curso Internacional Avanzado de Nutrición de Rumiantes, Centro de Ganadería, Colegio de Postgraduados, Montecillos, 25-31.

[9] Mendoza, M.G.D. and Ricalde, V.D. (1996) Suplementación de bovinos en crecimiento en Pastoreo. Ed. Universidad Autónoma Metropolitana, Unidad Xochimilco, México, $93 \mathrm{p}$.

[10] Aguirre, H.A., Bornios, H.F.C., Ramírez, R.O., Jiménez, G.R., Miguel, C.A. and Hernández, R.B. (2010) Respuesta productiva de becerros en pastoreo de praderas de pangola, suplementados con alimento comercial y harina de cacahuananche (Gliricidia sepium). REDVET, 11, 1-13. http://www.redalyc.org/articulo.oa?id=63613103013

[11] Aguirre, H.A., Ramírez, R.O., Pérez, P.J., Jiménez, G.R., Herrera, H.J. and Hernández, G.A. (2006) Rendimiento de una pradera de pangola y cambios de peso de becerros, por efecto de la inclusión de harina de cacahuananche (Gliricidia sepium) en el suplemento. REDVET, 7, 3-15. 
http://www.researchgate.net/publication/237038167

[12] García, E. (2004) Modificaciones al sistema de clasificación climática de Köeppen 4th edición, Instituto de Geografía, Universidad Nacional Autónoma de México, México, $217 \mathrm{p}$.

[13] SAS (2011) The SAS 9.2 for Windows. SAS Institute Inc., Cary.

[14] González, L.V. (2010) Efecto de la sustitución de la melaza por vainas de algarrobo (Ceratonia siliqua), en el comportamiento productivo de ovinos pelibuey en estabulación en, San José Estancia Grande, Oaxaca. Tesis Profesional, 59 p.

[15] Rojas, O.N. and Torres, R.C.H. (1998) Efectos de la sustitución de melaza por vainas de parota Enterolobium cyclocarpum, en el comportamiento productivo de ovinos pelibuey, en San José Estancia Grande, Oaxaca. Tesis Profesional. Instituto Tecnológico de Pinotepa, Oaxaca, 71 p.

[16] Alvarez, M.G., Malgarejo, V.L. and Castañeda, N.Y. (2003) Ganancia de peso, eficiencia y conversión alimentaria en ovinos alimentados con fruto (semilla con vaina) de parota Enterolobium cyclocarpum y pollinaza. Veterinaria México, 34, 3946.

[17] Emigdio, R.O. and Marín, G.I. (2009) Respuesta de ovinos pelibuey a la suplementación energético-proteica en la época seca, en San José Estancia Grande, Oaxaca, México. Memoria de Residencia Profesional. Instituto Tecnológico de Pinotepa, 70 p.

[18] Galindo, R.J.M. and Cruz, S.P. (2009) Cambios de peso de becerros alimentados con heno de pasto pangola y ensilado de pasto llanero y suplementados en la época seca, en San José Estancia Grande. 69 p. 